\title{
Pileate polypores from Araucaria Forests in Southern Brazil
}

\author{
Mauro Carpes Westphalen ${ }^{1,3}$ e Rosa Mara Borges da Silveira ${ }^{2}$
}

Received: 21.08.2012; accepted: 24.01.2013

\begin{abstract}
Pileate Polypores from Araucaria Forests in Southern Brazil). During a survey of polypores in the municipality of São Francisco de Paula, Rio Grande do Sul State, Brazil, 20 pileate species previously unregistered for the area were found and identified. Antrodia malicola, Coltricia aff. duportii, and Microporellus brasiliensis are new records for Rio Grande do Sul State. Comments on the 20 newly recorded species and an identification key for the studied area are presented.

Key words: Basidiomycota, diversity, neotropics, xylophilous fungi
\end{abstract}

RESUMO - (Políporos Pileados em áreas de Floresta com Araucária no Sul do Brasil). Durante o levantamento dos políporos do município de São Francisco de Paula, Rio Grande do Sul, Brasil, foram identificadas 20 espécies pileadas não registradas previamente para a região. Dentre estas, Antrodia malicola, Coltricia aff. duportii e Microporellus brasiliensis representam novas citações para o Estado do Rio Grande do Sul. São apresentados comentários sobre cada um desses novos registros e uma chave de identificação para as espécies na área de estudo.

Palavras-chave: Basidiomycota, diversidade, fungos xilófilos, neotrópicos

\section{Introduction}

The polypores are fungi and they are characterized by presenting a not easily detachable tubular hymenophore and being predominantly xylophilous. The priest J. Rick was the pioneer in the study of macroscopic fungi, including polypores, of Rio Grande do Sul (Fidalgo 1962, Rick 1960). After that, several other taxonomic researchers have been undertaken in the State on that group (Silveira \& Guerrero 1991, Groposo \& Loguercio-Leite 2002, Coelho et al. 2006, Reck \& Silveira 2008, Coelho et al. 2009, Westphalen et al. 2010, Reck et al. 2011, Westphalen et al. 2012). Silveira et al. (2008) did a survey of the pileate polypores from the São Francisco de Paula National Forest, providing a preliminary identification key for 38 species found in that study. More recently, another polypores survey was conducted in the municipality of São Francisco de Paula, RS, including collections of specimens in the National Forest, as well as the nearby areas. In this study, we present comments on 20 additional species previously unregistered from the studied area. Identification keys including all the 58 species in the region are presented.

\section{Material \& Methods}

Specimens were collected from April 2009 to May 2011 in the Mixed Ombrophilous Forest of the municipality of São Francisco de Paula, northeast of Rio Grande do Sul State, Southern Brazil. The Mixed Ombrophilous Forest is characterized by a subtropical vegetation with the dominance of the coniferous tree Araucaria angustifolia (Bertol.) Kuntze. The municipality of São Francisco de Paula is located at $912 \mathrm{~m}$ above sea level and comprehends an area of $3.274 \mathrm{~km}^{2}$. The climate in the region is of the Cfb type, according to Köppen Classification, with rainfall high in all months (average of $2.252 \mathrm{~mm}$ ) and average annual temperature of $14.5^{\circ} \mathrm{C}$ (Mota 1951, Backes 1999).

New collections were made in Floresta Nacional de São Francisco de Paula, Centro de Pesquisa e Conservação da Natureza Pró-Mata and nearby

1. Instituto de Botânica, Programa de Pós-Graduação em Biodiversidade Vegetal e Meio Ambiente, Av. Miguel Estefano 3687, 04301-902 São Paulo, SP, Brazil

2. Universidade Federal do Rio Grande do Sul, Departamento de Botânica, Programa de Pós-Graduação em Botânica, Av. Bento Gonçalves 9500, 91501-970 Porto Alegre, RS, Brazil

3. Corresponding author: maurowestphalen@yahoo.com.br 
areas. The collected basidiomes were preserved and analyzed macro and micromorphologically following usual methods for the study of polypores (Núñez \& Ryvarden 2001). For microscopy analysis, freehand sections of the basidiomes were mounted in microscope slides with a drop of 3\% $\mathrm{KOH}$ solution and $1 \%$ phloxine solution. Amyloid or dextrinoid reactions were observed in Melzer's reagent. All the specimens were deposited at ICN herbarium (Universidade Federal do Rio Grande do Sul, Brazil).

\section{Results and Discussion}

Twenty additional species not previously registered from the region were identified. Among them, Antrodia malicola, Coltricia aff. duportii and Microporellus brasiliensis are new records for Rio Grande do Sul State. Identification keys adapted from Silveira et al. (2008) are presented including all the species found in the region, as well as comments on the twenty species previously unregistered. Microscopic drawings of the newly recorded species and a image of $M$. brasiliensis are also presented.

Key to species of Hymenochaetaceae

1. Basidiomes stipitate from lateral to central

2. Context duplex with a distinct black line, basidiospores up to $4 \mu \mathrm{m}$ long Phylloporia spathulata

2. Context homogeneous, basidiospores $8-10 \mu \mathrm{m}$ long Coltricia aff. duportii

1. Basidiomes pileate, sessile or sometimes with a lateral tapering base

3. Hyphal system monomitic

4. Pileus surface soft and spongy, hymenial setae absent Phylloporia chrysita

4. Pileus surface tough to fibrous, hymenial setae present

5. Context homogeneus, hymenial setae usually hooked, basidiospores longer than $4 \mu \mathrm{m}$ Inonotus fulvomelleus

5. Context duplex, with one or two black lines, hymenial setae straight, basidiospores shorter than $4 \mu \mathrm{m}$ Cyclomyces tabacinus

3. Hyphal system dimitic

6. Hymenial setae present

7. Basidiomes perennial, hymenial setae hooked and straight Fuscoporia wahlbergii

7. Basidiomes annual, rarely perennial, hymenial setae always straight Fuscoporia gilva

6. Hymenial setae absent

8. Basidiospores hyaline, dextrinoid in Melzer's reagent. Fomitiporia apiahyna

8. Basidiospores golden yellow to rusty brown, undextrinoid

9. Basidiomes convex to semi-ungulate, basidiospores ellipsoid, 3-4 $\mu \mathrm{m}$ wide

9. Basidiomes aplanate, basidiospores subglobose, 4-5.5 $\mu \mathrm{m}$ wide

Phellinus grenadensis . Phellinus fastuosus

Key to species of other families

1. Basidiomes laterally to centrally stipitate

2. Basidiomes on the ground, basidiospores globose, with double walls

3. Basidiospores with inner wall ornamented, subglobose, 9-11.5 × 8-10 $\mu \mathrm{m}$ Amauroderma camerarium

3. Basidiospores with inner wall smooth, globose, $6.5-7 \mu \mathrm{m}$ wide Amauroderma coltricioides

2. Basidiomes on dead wood, basidiospores cylindrical to ellipsoid, with simple walls

4. Pileus surface tuberculate, cystidia present, with skeletal hyphae Microporellus brasiliensis

4. Pileus surface smooth to finely striated, cystidia absent, with skeleto-binding hyphae

5. Stipe central, beige to light brown, concolorous with pileus surface Polyporus ciliatus

5. Stipe eccentric to lateral, dark brown to black or with a dark colored base

6. Pileus flabelliform to petaloid, pores white to cream Polyporus virgatus

6. Pileus circular to spathulate, pore surface grayish to brownish

7. Pileus surface cream to light brown, smooth to radially finely striate Polyporus varius

7. Pileus surface brown to vinaceous brown, smooth Polyporus dictyopus

1. Basidiomes effused-reflexed, sessile or sometimes with a lateral tapering base 8. Hymenophore irpicoid, dentate, daedaloid or lamellate 
9. Hymenophore irpicoid to dentate, sometimes poroid at the margins, hyphal system monomitic, generative hyphae with simple septa

Irpex lacteus

9. Hymenophore daedaloid to lamellate, hyphal system trimitic, generative hyphae with clamps Lenzites betulina

8. Hymenophore strictly poroid

10. Basidiospores truncate, golden-brown, with double walls, ornamented Ganoderma australe

10. Basidiospores globose to cylindrical, hyaline, with simple walls, smooth

11. Generative hyphae with simple septa

12. Hyphal system dimitic with binding hyphae, basidiospores ellipsoid

Laetiporus cf. sulphureus

12. Hyphal system monomitic, basidiospores globose to subglobose

13. Basidiomes laterally attached by a distinct umbo or by a tapering base

13. Basidiomes effused-reflexed to dimidiate

Rigidoporus concrescens

14. Basidiomes white to cream, soft, hyphae more or less unchanged when dried

Oxyporus obducens

14. Basidiomes pinkish-orange, tough when fresh and very hard when dried, hyphae agglutinated when dried

15. Basidiomes large up to $6 \mathrm{~cm}$ thick, basidiospores $5-10 \mu \mathrm{m}$ wide ... Rigidoporus ulmarius

15. Basidiomes smaller up to $1 \mathrm{~cm}$ thick, basidiospores 3.5-5 $\mu \mathrm{m}$ wide

16. Cystidia absent

Rigidoporus microporus

16. Cystidia present

Rigidoporus lineatus

11. Generative hyphae with clamps

17. Basidiomes perennial, basidiospores pip-shaped to truncate, dextrinoid and thick-

walled

18. Basidiomes large, up to $7 \mathrm{~cm}$ thick, pileus surface dark bay to dark brown ... Perenniporia martii

18. Basidiomes smaller, up to $2.5 \mathrm{~cm}$ thick, pileus surface cream ochraceous

19. Basidiospores truncate, up to $16 \mu \mathrm{m}$ long

Perenniporia ochroleuca

19. Basidiospores pip-shaped, up to $4 \mu \mathrm{m}$ long ........... Perenniporiella neofulva

17. Basidiomes annual, basidiospores different shaped, undextrinoid and thin-walled

20. Cystidia present in the hymenium or trama

21. Cystidia thin-walled

22. Basidiomes pinkish-red, basidiospores slightly thick-walled

22. Basidiomes white, cream or yellowish, basidiospores thin-walled

Aurantiporus pulcherrimus

23. Basidiomes soft, more or less unchanged when dried, basidiospores allantoid .......

Tyromyces hypocitrinus

23. Basidiomes waxy, becoming very hard and darkening upon drying, basidiospores ellipsoid

Flaviporus liebmanii

21. Cystidia thick-walled

24. Pore surface grayish to vinaceous, basidiospores cylindrical to ellipsoid

Trichaptum sector

24. Pore surface light to vivid colored, basidiospores broadly ellipsoid to subglobose

25. Pore surface sulphur yellow

Flaviporus brownii

25. Pore surface cream

26. Basidiomes brittle, pores 7-9 per mm, basidiospores 2.5-3 $\times 2-2.5 \mu \mathrm{m}$

Junghuhnia minuta

26. Basidiomes flexible, pores 5-7 per mm, basidiospores 4-5 × 3.5-4 $\mu \mathrm{m}$

20. Cystidia absent

Junghuhnia undigera

27. Hyphal system monomitic

28. Pore surface white, basidiospores allantoid

Tyromyces leucomallus 
28. Pore surface smoke gray to blackish, basidiospores short-cylindrical

29. Tubes pale gray, context white to cream with a black line..... Bjerkandera adusta

29. Tubes brownish-gray, context concolorous with the tubes, without a black line Bjerkandera fumosa

27. Hyphal system di-trimitic

30. Hyphal system dimitic to pseudo-trimitic

31. Hyphal system pseudo-trimitic, strongly branched skeletal hyphae and/or skeleto-binding hyphae present

32. Pore surface vinaceous to vinaceous brown, basidiospores yellowish and ellipsoid, $4-5 \times 2.5-3 \mu \mathrm{m}$ Abundisporus subflexibilis

32. Pore surface beige to brownish-gray, basidiospoes hyaline and cylindrical, 7.5-11 ×3-4.5 $\mu \mathrm{m}$. Datronia mollis

31. Hyphal system strictly dimitic, only unbranched to rarely branched skeletal hyphae present

33. Pileus surface hirsute, with hydnoid processes and clamped asexual spores ..... Echinoporia aculeifera

33. Pileus surface glabrous to tomentose, without hydnoid processes, clamped asexual spores absent

34. Pore surface white, cream, beige or light brown, pileus surface glabrous to velutinous

35. Context monomitic, skeletal hyphae present only in the trama

36. Pileus surface beige to pale brown, basidiospores up to $1.5 \mu \mathrm{m}$ wide Antrodiella duracina

36. Pileus surface bright reddish-orange, basidiospores 1.5-2 $\mu$ m wide Flaviporus subhydrophilus

35. Context dimitic, skeletal hyphae present throughout the basidiomes

37. Basidiospores ellipsoid Antrodiella multipileata

37. Basidiospores cylindrical to allantoid

38. Basidiomes toughtocorky, basidiospores 7-10 $\times 2.5-4 \mu \mathrm{m}$, causing a brown-rot in the wood . Antrodia malicola 38. Basidiomes fleshy to cartilaginous, basidiospores 4-8 $\times 2-2.5 \mu \mathrm{m}$, causing a white-rot in the wood

Diplomitoporus marianoi-rochae

34. Pore surface greyish brown vinaceous brown, pileus surface tomentose

39. Pores irregular, basidiospores cylindrical, 5-7 $\times 2-2.5 \mu \mathrm{m}$, dendrohyphidia present in the hymenium .... Fuscocerrena portoricensis

39. Pores regular, basidiospores allantoid, 3-4.5 $\times 0.5-1 \mu \mathrm{m}$, dendrohyphidia absent Skeletocutis roseola

30. Hyphal system trimitic

40. Basidiomes orange-red Pycnoporus sanguineus

40. Basidiomes differently colored

41. Pore surface dark, brownish grey to dark grey Fomitella supina

41. Pore surface light-coloured, cream to ochraceous

42. Pileus surface ochraceous to pale cinnamon-brown, context yellowish Coriolopsis rigida

42. Pileus surface cream, brown or grey, context white 43. Pores 8-10 per mm, basidiospores allantoid, up to $1 \mu \mathrm{m}$ wide, hyphal pegs abundant Skeletocutis nivea 
43. Pores larger, 1-7 per mm, basidiospores cylindrical to ellipsoid, at least $1.5 \mu \mathrm{m}$ wide, hyphal pegs absent to sparse 44. Pores 1-4 per mm, pileus surface strigose to hirsute 45. Basidiomes thin, up to $2 \mathrm{~mm}$ thick, context homogeneus ..... Trametes villosa

45. Basidiomes thicker, at least $3 \mathrm{~mm}$ thick, context duplex, with a black line separating the layers Trametes hirsuta

44. Pores 5-7 per mm, pileus surface tomentose, velutinate or glabrous

46. Basidiomes large, up to $10 \mathrm{~cm}$ wide, basidiospores 7-9.5 $\mu \mathrm{m}$ long Trametes cubensis

46. Basidiomes smaller, up to $5.5 \mathrm{~cm}$ wide, basidiospores up to $6.5 \mu \mathrm{m}$ long 47. Pileus surface with more or less distinct cream to light brown zones Trametes membranacea 47. Pileus surface strongly zonate in shades of brown and gray Trametes versicolor

Amauroderma camerarium (Berk.) J.S. Furtado, Revisão do genero Amauroderma:140. 1968

Description in: Furtado (1981)

Species characterized by the thin and glabrous pileus surface and the thin and long stipe. Microscopically it presents yellowish basidiospores with conspicuous endosporic projections and pilear cover as a cortex formed by skeletal hyphae.

Examined specimens: BRAZIL. Rio GRANDE Do Sul: São Francisco de Paula, FLONA, 26-III-2009, M.C. Westphalen 294/10 (ICN); M.C. Westphalen 300/10 (ICN); M.C. Westphalen 307/10 (ICN).

Antrodia malicola (Berk. \& M.A. Curtis) Donk, Persoonia 4(3): 339. 1966

Figure 1A

Description in: Gilbertson \& Ryvarden (1986)

Species characterized by the more or less uniform beige to light brown basidiomes with regular to sinuous pores, large cylindrical basidiospores and by causing brown rot in the wood. This is the first record of the species from Rio Grande do Sul State. In Brazil, it was previously recorded only from Paraná State (Meijer 2008).

Examined specimens: BRAZIL. Rio Grande Do Sul: São Francisco de Paula, CPCN Pró-Mata, 25-VI-2010, M.C. Westphalen 330/10 (ICN); M.C. Westphalen $331 / 10$ (ICN).
Antrodiella duracina (Pat.) I. Lindblad \& Ryvarden, Mycotaxon 71:336. 1999

Description in: Lindblad \& Ryvarden (1999)

Antrodiella duracina is characterized by the corky cream colored basidiomes with small pores, dimitic hyphal system with monomitic context (skeletal hyphae only in trama) and allantoid basidiospores. Antrodiella versicutis (Berk. \& M.A. Curtis) Gilb. \& Ryvarden is a very similar species, but it differs in presenting a dimitic context.

Examined specimens: BRAZIL. Rio GRANDE do SuL: São Francisco de Paula, FLONA, 22-VI-2009, M.A. Reck 124/09 (ICN), M.A. Reck 129/09 (ICN).

Aurantiporus pulcherrimus (Rodway) P.K. Buchanan \& Hood, New Zealand J. Bot. 30: 96. 1992

Description in: Buchanan \& Hood (1992)

This species is easily recognizable by its red to reddish-pink basidiomes with large pores (2-4 per $\mathrm{mm}$ ) and fleshy to cartilaginous consistency that shrink and become very hard upon drying. Microscopically, it presents monomitc hyphal system, subglobose basidiospores and abundant thin-walled cystidia. Aurantiporus pulcherrimus was previously recorded from Rio Grande do Sul State by Silveira \& Guerrero (1991) as Spongipellis aff. caseosus (Pat.) Ryvarden.

Examined specimens: BRAZIL. Rio GRANDE do SUL: São Francisco de Paula, CPCN Pró-Mata, 14-IX-2009, 
M.C. Westphalen 290/09 (ICN); 25-VI-2010, M.C. Westphalen 329/10 (ICN).

Bjerkandera fumosa (Pers.) P. Karst., Meddel. Soc. Fauna Fl. Fenn. 5: 38. 1879

Description in: Ryvarden \& Gilbertson (1993)

Species characterized by the grayish basidiomes, monomitc hyphal system and subcylindrical basidiospores. Bjerkandera fumosa is similar to B. adusta (Willd.) P. Karst., but it differs in paler tubes, presence of a dark line between the tubes and the context and longer basidiospores. Moreover, the basidiomes $B$. fumosa are often laterally fused, while in B. adusta they are usually solitary.

Examined specimens: BRAZIL. Rio Grande DO Sul: São Francisco de Paula, CPCN Pró-Mata, 26-IX-2009, M.A. Reck 224/09 (ICN); Hotel Veraneio Hampel, 27-III-2010, M.C. Westphalen 314/10 (ICN).

Coltricia aff. duportii (Pat.) Ryvarden Occas. Pap. Farlow Herb. 18: 140. 1984

Figure 1B

Description in: Ryvarden (1983)

Coltricia duportii is a rare species described from Guinea (Pattouilard 1912, Ryvarden 1983) and later found in Paraná State, Southern Brazil (Rajchenberg $\&$ Meijer 1990). It is characterized by the stipitate basidiomes with velutinate pileus surface and the large rusty brown basidiospores $(8-10 \times 6-7 \mu \mathrm{m})$. Our specimen was found growing on the stipe of a living Dicksonia sellowiana Hook., differing from what was described by the other authors (op. cit.), where they were found growing on the base of living palm trees. However, Ryvarden \& Meijer (2002) cited another specimen of $C$. duportii from Paraná State growing in a living dicotyledonous tree, so it seems that the substratum may be variable. Moreover, Ryvarden (op. cit.) described the pores of C. duportii as 2-3 per $\mathrm{mm}$, while in our material they are smaller (4-7 per mm). Further investigation on the species, also including molecular data, could help resolving this morphological and host variation and confirming the identity of our specimen.

Examined specimen: BRAZIL. Rio Grande do Sul: São Francisco de Paula, CPCN Pró-Mata, 7-V-2011, J.M. Baltazar \& L.T. Pereira JMB 2491 (ICN).

Diplomitoporus marianoi-rochae G. Coelho, Fungal Planet no. 26, 2008

Description in: Coelho (2008)
The species is characterized by the effused-reflexed to almost completely resupinate fleshy to cartilaginous basidiomes with large white pores (0.5-2 per mm). Microscopically it can be recognized by the allantoid spores (3.5-9.5 $\times 1.5-3 \mu \mathrm{m})$ and abundant hyphidia or dendrohyphidia in fresh basidiomes. This species was previously recorded only from its type locality Santa Maria, also on Rio Grande do Sul State (Coelho 2008).

Examined specimen: BRAZIL. Rio Grande do Sul: São Francisco de Paula, CPCN Pró-Mata, 7-V-2011, M.C. Westphalen 344/11 (ICN).

Echinoporia aculeifera (Berk. \& M.A. Curtis) Ryvarden, Mycotaxon 20(2): 330. 1984

Description in: Gilbertson \& Ryvarden (1986)

This species is easily recognized in the field by its orange to brown hirsute pileus surface, with hydnoid processes, and by its beige to light-brown hymenial surface, with irregular to daedaloid pores and often dilacerate dissepiments.

Examined specimens: BRAZIL. Rio Grande do Sul: São Francisco de Paula, CPCN Pró-Mata, 26-IX-2009, M.C. Westphalen 278/09 (ICN); 14-XI-2009, M.C. Westphalen 281/09 (ICN); 26.VI.2010, M.C. Westphalen 332/10 (ICN).

Fuscocerrena portoricensis (Spreng. ex Fr.) Ryvarden, Trans. Brit. Mycol. Soc. 79(2): 279. 1982

Description in: Gilbertson \& Ryvarden (1986)

The species is normally easy to recognize due to the dark brown to vinaceous brown pileus and the irregular hymenophore that becomes strongly split to dentate with age. Such characteristics are similar to those of Hydnochaete Bres. species, but the latter present a more rusty brown color, generative hyphae with simple septa and setae.

Examined specimens: BRAZIL. Rio Grande Do Sul: São Francisco de Paula, FLONA, 24-IV-2009, M.C. Westphalen 160/09 (ICN); 18-V-2009, M.C. Westphalen 186/09 (ICN).

Irpex lacteus $\mathrm{Fr}$. (Fr.), Elench Fung. 1:145. 1828

Description in: Ryvarden \& Gilbertson (1993)

Macroscopically, Irpex lacteus is characterized by the cream colored effused-reflexed basidiomes with irregular hymenophore, at first poroid $\left(2-3 \mathrm{~mm}^{-1}\right)$, and latter becoming strongly split, irpicoid to hidnoid. Microscopically it presents incrusted cystidia and 
generative hyphae with simple septa. On the studied area, this species was found growing on dead branches of Baccharis uncinella DC., what was also observed by Silveira \& Guerrero (1991).

Examined specimens: BRAZIL. Rio GRANDE Do SUL: São Francisco de Paula, CPCN Pró-Mata, 26-VI-2010, M.C. Westphalen 333/10 (ICN); M.C. Westphalen 334/10 (ICN).

Microporellus brasiliensis Ryvarden \& Decock, Czech Mycol. 54(1-2): 23. 2002

Figures 1C-D, 2

Description in: Decock \& Ryvarden (2002)

Microporellus brasiliensis can be easily identified by the beige to grayish, hard, stipitate to sub-stipitate basdiomes with tuberculate pileus surface. Microscopicallly, the apically incrusted fusoid to ventricose cystidia, the strongly dextrinoid vegetative hyphae and the subglobose to drop-shaped basidiospores with slightly thickened walls are diagnostic features of the species. This is the first record of the species for Rio Grande do Sul State, which was previously know only from Paraná State, where it was described (Decock \& Ryvarden 2002, Meijer 2006).

Examined specimen: BRAZIL. Rio GRANDE DO SUL: São Francisco de Paula, FLONA, 24-V-2010 M.C. Westphalen 327/10 (ICN).

Oxyporus obducens (Pers.) Donk, Meddel. Bot. Mus. Herb. Rijhs Universit. Utrecht. 9: 202. 1933.

Description in: Robledo \& Urcelay (2009)

The species is characterized by the white to cream-colored, effused-reflexed, soft basidiomes.

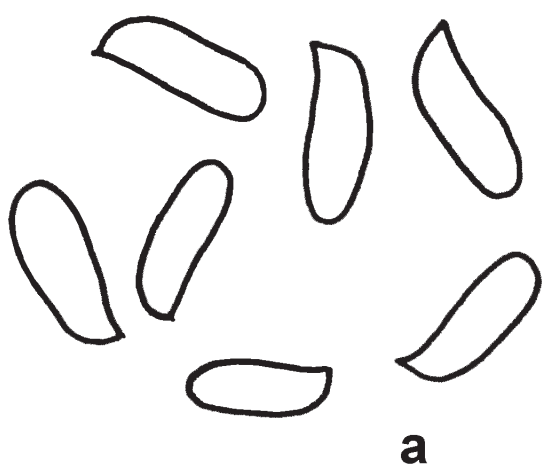

a

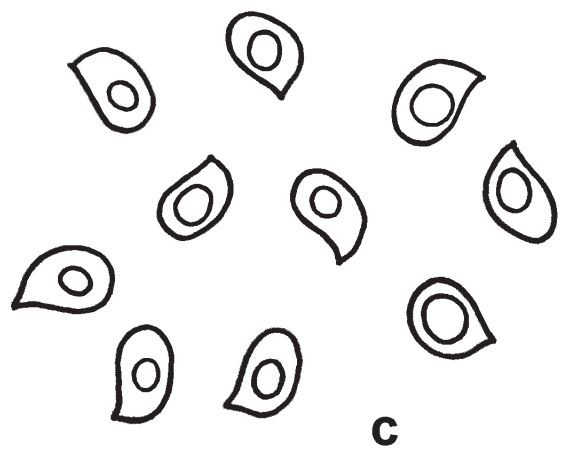

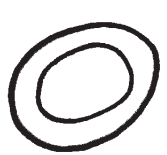
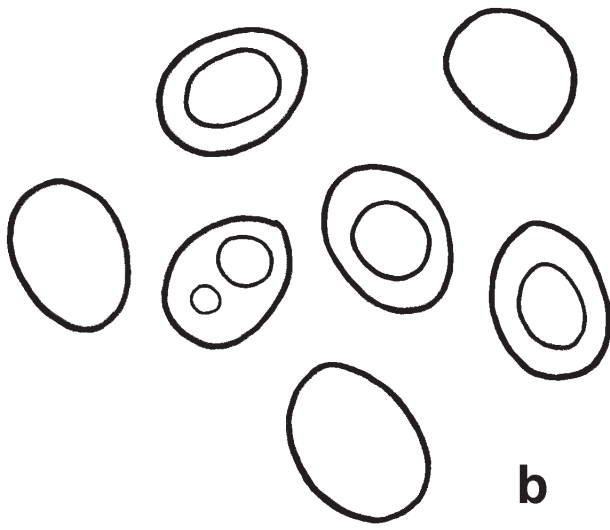

흘
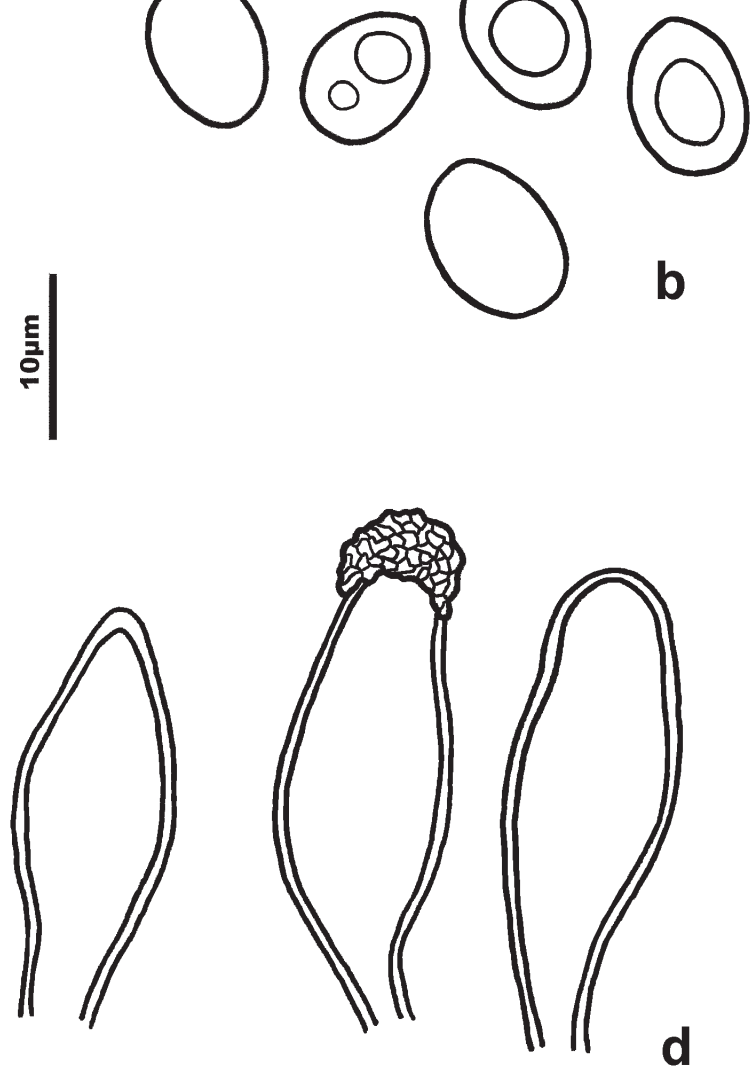

Figure 1. A. Basidiospores of Antrodia malicola. B. Basidiospores of Coltricia aff. duportii. C-D. Microporellus brasiliensis. C. Basidiospores. D. Cystidia. 
Microscopically, the species can be identified by the monomitic hyphal system with simple-septate hyphae, subglobose basidiospores, thick-walled cystidia with an apical crown of crystals and the presence of chlamydospores. The pileus surface of this species is often found in the field tinged green due to the presence of algae.

Examined specimens: BRAZIL. Rio Grande do Sul: São Francisco de Paula, FLONA, 24-IV-2009, M.C. Westphalen 159/09 (ICN); 24-V-2010, M.C. Westphalen 323/10 (ICN); M.C. Westphalen 326/10 (ICN); CPCN Pró-Mata, 29-V-2009, M.A. Reck 103/09 (ICN); 26-VI-2010, M.C. Westphalen 336/10 (ICN).

Perenniporia ochroleuca (Berk.) Ryvarden, Norweg. J. Bot. 19: 143. 1972

Description in: Ryvarden \& Johansen (1980)

This species can be recognized by the pileate basidiomes with cream to pale brown sulcate pileus surface, the light-colored hymenophore with relatively large pores $\left(2-5 \mathrm{~mm}^{-1}\right)$ and the large $(12-18 \times 7-11 \mu \mathrm{m})$, truncate, strongly dextrinoid spores.

Examined specimen: BRAZIL. Rio Grande Do Sul: São Francisco de Paula, CPCN Pró-Mata, 7-V-2011, M.C. Westphalen 341/11 (ICN).

Perenniporiella neofulva (Lloyd) Decock \& Ryvarden, Mycol. Res. 107(1): 94. 2003

Description in: Decock \& Ryvarden (2003)

Perenniporiella neofulva is characterized by its cream to light brown, glabrous, sulcate pileus, and small pores $\left(5-9 \mathrm{~mm}^{-1}\right)$. Microscopically the small (up to $4 \mu \mathrm{m}$ in diam.), weakly dextrinoid, subglobose to globose spores that often become withered and appear to be angular in dried specimens and are diagnostic features of the species.

Examined specimens: BRAZIL. Rio GRANDE do SuL: São Francisco de Paula, FLONA, 24-IV-2009, M.A. Reck 040/09 (ICN); CPCN Pró-Mata, 29-V-2009, M.C. Westphalen 215/09 (ICN).

Phylloporia chrysita (Berk.) Ryvarden, Norw. Jl Bot. 19: 235. 1972.

Description in: Ryvarden (2004)

Phylloporia chrysita is easily identified by the light, spongy basidiomes, with brown upper surface and yellow hymenophore, and context with a distinct black line. Microscopically, it is characterized by monomitic hyphal system and the small, subglobose, indextrinoid spores. This species is usually found growing on living lianas.

Examined specimen: BRAZIL. Rio GRANDE do Sul: São Francisco de Paula, CPCN Pró-Mata, 25-VI-2010, Campos-Santana 266/10 (ICN).

Rigidoporus lineatus (Pers.) Ryvarden, Norw. Jl Bot. 19: 236. 1972.

Description in: Ryvarden \& Johansen (1980)

This species is characterized by the effusedreflexed basidiomes with orange pore surface that become very hard after dried. Microscopically, it presents monomitic hyphal system, metuloid cystidia, often apically incrusted, and globose to subglobose basidiospores, usually with one large oil-drop. Rigidoporus microporus (Sw.) Overeem is a very similar species, differing only by lacking cystidia.

Examined specimens: BRAZIL. Rio Grande do Sul: São Francisco de Paula, FLONA, 26-III-2010, M.C. Westphalen 297/10 (ICN); Hotel Veraneio Hampel, 27-III-2010, M.C. Westphalen 318/10 (ICN).

Skeletocutis nivea (Jungh.) Jean Keller, Persoonia 10(3): 353. 1979

Description in: Ryvarden \& Gilbertson (1994)

Species recognizable by the small, white, tough basidiomes, usually effuse-reflexed and imbricate. Microscopically, it is characterized by the trimitic hyphal system, the very narrow allantoid basidiospores (0.5-1 $\mu \mathrm{m}$ wide) and the presence of hyphal pegs. This is second record of the species from Brazil. It was previously registered by Rick (1960), also from Rio Grande do Sul State, as Poria consimilis Rick, and later identified as $S$. nivea by Rajchenberg (1987).

Examined specimens: BRAZIL. Rio Grande do Sul: São Francisco de Paula, CPCN Pró-Mata, 29-V-2009, M.A. Reck 108/09 (ICN); FLONA, 04.VI.2010, M.A. Reck 431/10 (ICN).

Skeletocutis roseola (Rick ex Theiss.) Rajchenb., Nordic J. Bot. 7(5): 561. 1987.

Description in: Rajchenberg (1987)

Macroscopically, Skeletocutis roseola can be recognized by the thin basidiomes with vinaceousbrown hymonophore, beige to grayish tomentose pileus surface and duplex context, formed by an upper 


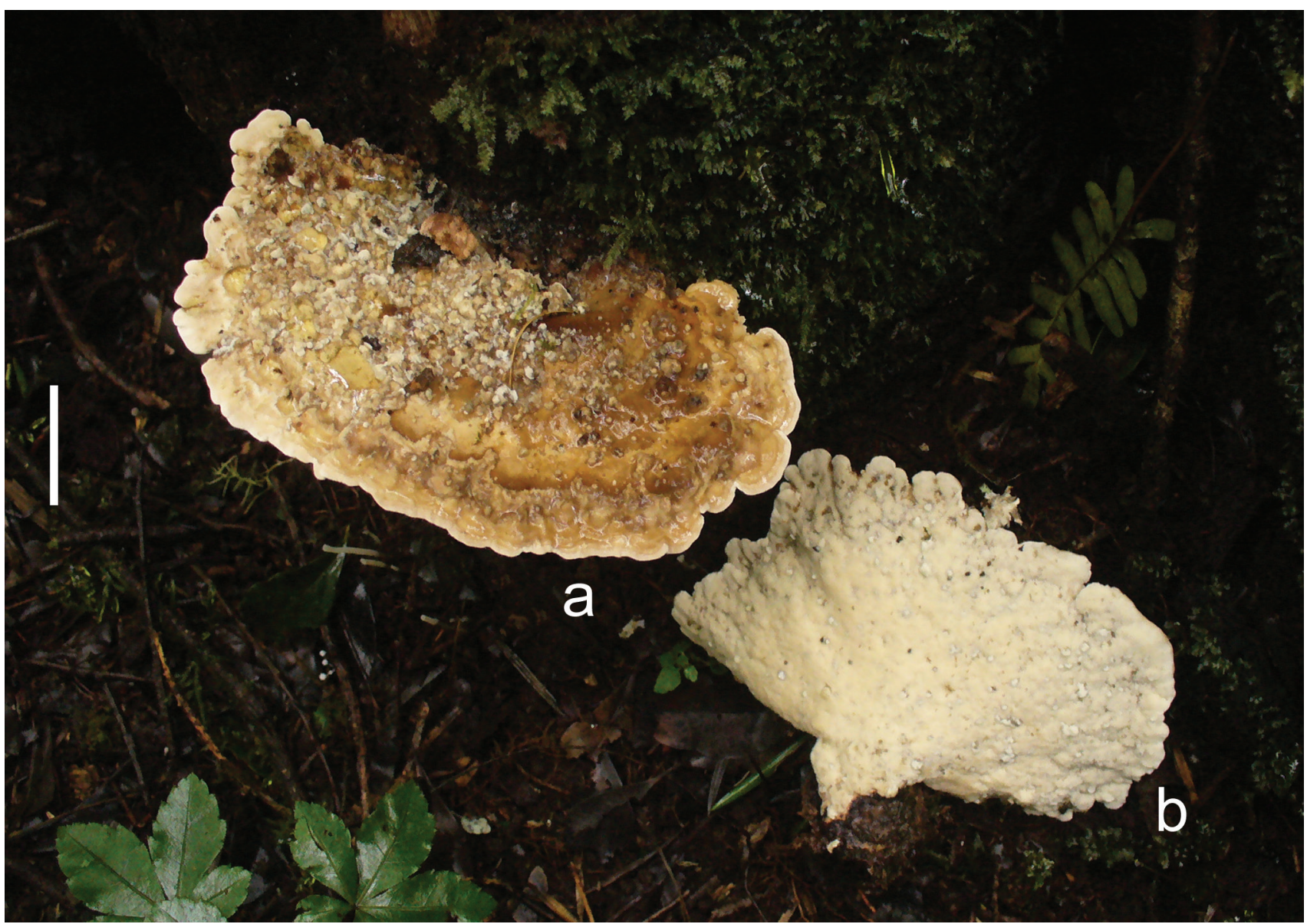

Figure 2. A-B. Basidiomes of Microporellus brasiliensis. A. Pileus surface. B. Pore surface. (Image by M.A. Reck). Scale bar: $2 \mathrm{~cm}$.

white cottony layer and a lower brown gelatinous layer. Microscopically it is distinguished by the very narrow allantoid basidiospores (0.5-1 $\mu \mathrm{m}$ wide).

Examined specimens: BRAZIL. Rio GRANDE DO Sul: São Francisco de Paula, FLONA, 24-IV-2009, M.C. Westphalen 149/09 (ICN); 22-VI-2009, M.C. Westphalen 232/09 (ICN); 24-V-2010, M.C. Westphalen 328/10 (ICN).

Trametes hirsuta (Wulfen) Lloyd, Mycol. Writ. 7(73): 1319. 1924

Description in: Ryvarden \& Gilbertson (1994)

This species can be recognized by its hirsute and zonate in shades of gray pileus surface, large pores, and the presence of a dark line in the context. Trametes villosa (Fr.) Kreisel is a similar species, differing in smaller and thinner basidiomes and the lack of a black line in the context.

Examined specimen: BRAZIL. Rio GRANDE Do SUL: São Francisco de Paula, CPCN Pró-Mata, 14-XI-2009, M.C. Westphalen 287/09 (ICN).
Trametes versicolor (L.) Lloyd, Mycol. Writ. 6(65): 1045. 1920

Description in: Ryvarden \& Johansen (1980)

Trametes versicolor is a common cosmopolitan species, being recognized mostly by its silky and tomentose pileus surface, zonate in shades of brown and gray, and by its white hymenophore. Trametes membranacea (Sw. ex Fr.) Kreisel is a similar species that can be differentiated by the lighter, cream-colored, pileus surface.

Examined specimes: BRAZIL. Rio Grande Do Sul: São Francisco de Paula, CPCN Pró-Mata, 20-V-2009, M.A. Reck 100/09 (ICN); FLONA, 22-VI-2009, M.A. Reck 125/09 (ICN).

\section{Acknowledgments}

CAPES (Brazil) is acknowledged for financial support. We also would like to thank MsC. Juliano Marcon Baltazar for the assistance in the identification and for the comments on Coltricia aff. duportii, and MsC. Mateus Arduvino Reck for the M. brasiliensis image. 


\section{Literature cited}

Backes A. 1999. Condicionamento climático e distribuição geográfica de Araucaria angustifolia (Bertol.) Kuntze no Brasil - II. Pesquisas - Botânica 49: 31-51.

Buchanan, P.K. \& Hood, I.A. 1992. New species and new records of Aphyllophorales (Basidiomycetes) from New Zealand. New Zealand Journal of Botany 30: 95-112

Coelho, G. 2008. Diplomitoporus marianoi-rochae. Fungal Planet 26. http://www.fungalplanet.org/content/ pdf-files/The\%20Fungal\%20Planet $\% 2026 \_\% 20$ Diplomitoporus\%20marianoi-rochae\%208feb08_2.pdf (access in 31.01.2013).

Coelho, G., Silveira, R.M.B. \& Rajchenberg, M. 2006. A new Gloeoporus species growing on bamboo from southern Brazil. Mycologia 98: 821-827.

Coelho, G., Silveira, R.M.B., Guerrero, R.T. \& Rajchenberg, M. 2009. On poroid Hymenochaetales growing on bamboos in Southern Brazil and NE Argentina. Fungal Diversity 36: 01-08.

Decock, C. \& Ryvarden, L. 2002. Two undescribed Microporellus species and notes on M. clemensiae, M. setigerus and M. subincarnatus. Czech Mycology 54: 19-30.

Decock, C. \& Ryvarden, L. 2003. Perenniporiella gen. nov. segregated from Perenniporia including a key to neotropical Perenniporia species with pileate basidiomes. Mycological Research 107: 93-103.

Fidalgo, O. 1962. Rick, o pai da micologia brasileira. Rickia 1: 1-11.

Furtado. J.S. 1981. Taxonomy of Amauroderma (Basidiomycetes, Polyporaceae). Memoirs of the New York Botanical Garden 34: 1-109.

Gilbertson, R.L. \& Ryvarden, L. 1986. North American polypores. Abortiporus - Lindtneria. v.1. Fungiflora, Oslo.

Groposo, C. \& Loguercio-Leite, C. 2002. Fungos poliporóides (Basidiomycetes) da Reserva Biológica Tancredo Neves, Cachoeirinha, Rio Grande do Sul, Brasil. Iheringia, Série Botânica 57: 39-59.

Lindblad, I. \& Ryvarden, L. 1999. Studies in Neotropical polypores. 3. New and interesting Basidiomycetes (Poriales) from Costa Rica. Mycotaxon 71: 335-359.

Meijer, A.A.R. 2008. Macrofungos notáveis das florestas de pinheiro-do-paraná. Embrapa Florestas, Colombo.

Mota, F.S. 1951. Estudos do clima do Estado do Rio Grande do Sul, segundo o sistema de W. Köppen. Revista Brasileira de Geografia 13: 275-284.

Núñez, M. \& Ryvarden, L. 2001. East Asian polypores. Synopsis Fungorum 13: 1-168.
Patouillard, N. 1912. Quelques Champignons de la Guinee Francaise. Bulletin de la Société Mycologique de France 28: 31-37.

Rajchenberg, M. 1987. Type studies of Polyporaceae (Aphyllophorales) described by J. Rick. Nordic Journal of Botany 7: 553-568.

Rajchenberg, M. \& Meijer A.A.R. 1990. New and noteworthy polypores from Paraná and São Paulo States, Brazil. Mycotaxon 38: 173-185.

Reck, M.A. \& Silveira, R.M.B. 2008. Ordem Polyporales (Basidiomycota) no Parque Estadual de Itapuã, Viamão, Rio Grande do Sul. Revista Brasileira de Biociências 6: 301-314.

Reck, M.A., Westphalen, M.C. \& Silveira, R.M.B. 2011. Rediscovery of Microporellus iguazuensis in Southern Brazil. Mycotaxon 115: 5-10.

Rick, J. 1960. Basidiomycetes Eubasidii in Rio Grande do Sul - Brasilia 4. Meruliaceae, Polyporaceae e Boletaceae. Iheringia Série Botânica 7: 193-295.

Robledo, G. L. \& Urcelay, C. 2009. Hongos de La Madera em Árboles Nativos Del Centro de Argentina. Editorial Universitaria, Universidad Nacional de Córdoba, Córdoba.

Ryvarden, L. 1983. Type studies in the Polyporaceae. 16. Species described by N. Patouillard, either alone or with other mycologists. Occasional Papers of Farlow Herbarium of Cryptogamie Botany 18: 1-38.

Ryvarden, L. 2004. Neotropical Polypores. Part 1. Synopsis Fungorum 19: 1-229.

Ryvarden, L ; Gilbertson, R. L. 1993. European Polypores. Fungiflora, Oslo.

Ryvarden, L ; Gilbertson, R. L. 1994. European Polypores. Fungiflora, Oslo.

Ryvarden, L. \& Johansen, I. 1980. A preliminary Polypore Flora of East Africa. Oslo, Fungiflora.

Ryvarden, L. \& Meijer, A.A.R. 2002. Studies in neotropical polypores. 14. New species from the state of Paraná, Brazil. Synopsis Fungorum 15: 34-69.

Silveira, R.M.B. \& Guerrero R.T. 1991. Aphyllophorales poliporóides (Basidiomycetes) do Parque Nacional de Aparados da Serra, RS. Boletim do Instituto de Biociências 48: 1-147.

Silveira, R.M.B., Reck, M.A., Graf, L.V. \& Nogueira de Sá, F. 2008. Polypores from a Brazilian pine Forest in Southern Brazil: pileate species. Hoehnea 35: 619-630.

Westphalen, M.C., Reck, M.A. \& Silveira R.M.B. 2010. Polypores from Morro Santana, Rio Grande do Sul, Brazil. Hoehnea 37: 645-661.

Westphalen, M.C., Reck, M.A. \& Silveira, R.M.B. 2012. The Genus Junghuhnia in Brazil. Nova Hedwigia 94: 209-220. 